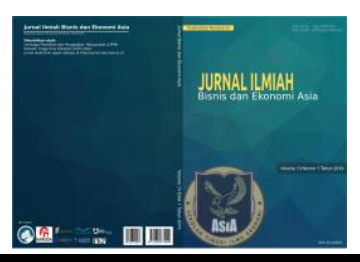

\title{
Peran Sistem Informasi Pemasaran, Kualitas Pelayanan dan Entrepreneurial marketing serta Kepuasan Terhadap Loyalitas Generasi Milenial Berkunjung ke Tempat Wisata
}

Syarif Hidayatullah ${ }^{1 *}$, Ike Kusdyah Rachmawati ${ }^{2}$, Eko Aristanto ${ }^{3}$, Abdul Waris $^{4}$, Ryan Gerry Patalo ${ }^{5}$ 1,3,5Universitas Merdeka Malang, ${ }^{2}$ Institut ASIA Malang, ${ }^{4}$ Politeknik Negeri Malang

\section{INFO ARTIKEL}

DOI:10.32812/jibeka.v14i1.148

ISSN-P: 0126-1258

ISSN-E: 2620-875X

Keywords:Marketing information Systems, Entrepreneurial marketing, Loyalty and Millennial
Kata Kunci: Sistem Informasi pemasaran, Entrepreneurial marketing, Loyalitas dan Millenial

\begin{abstract}
The diversity of tourist attractions in the Jatim Park Group is inseparable from entrepreneurial marketing that is applied by companies with the use of mature market research and in order to support Batu City to become an International Destination City. This study illustrates the influence of marketing information systems, service quality and customer satisfaction on customer loyalty. East Java park group with 6 reservoirs is the location of the study with a total sample of 120 people, with characteristics of millennial age samples (aged between 15-34 years). The results of the research show that the marketing information system does not directly influence loyalty but the marketing information system influences loyalty through the marketing information system, as well as the results of service quality which directly or indirectly affect customer loyalty. The entrepreneurial marketing also has a direct or non-slim influence on customer loyalty through customer satisfaction. This shows the existence of tourist attractions is very necessary the existence of product innovation and differentiation as well as informing customers with an updated marketing information system and still continuing to maintain services if visitors are already in the tourist attractions.
\end{abstract}

\section{ABSTRAK}

Keanekaragaman tempat wisata yang ada di Jatim Park Group tidak terlepas dari entrepreneur Marketing yang diterapkan oleh perusahaan dengan penggunaan riset pasar yang matang serta dalam rangka mendukung Kota Batu menjadi Kota Destinasi Internasional. Penelitian ini menggambarkan pengaruh dari sistim informasi pemasaran, kualitas pelayanan dan kepuasan pelanggan terhadap loyalitas pelanggan. Jatim park group dengan 6 wahananya menjadi lokasi penelitian dengan jumlah sampel sebanyak 120 orang, dengan karakteristik sampel usia milenial (usia antara 15-34 tahun). Hasil penelitian meninjukan sistem informasi pemasaran tidak berpengaruh secara langsung terhadap loyalitas tetapi sistem informasi pemasaran berpengaruh terhadap loyalitas malalui sistem informasi pemasaran, demikian halnya hasil dari kualitas pelayanan yang dengan langsung maupun tidak langsung berpengaruh terhadap loyalitas pelanggan. Adapun entrepreneurial marketing juga ada pengaruh langsung maupun tidak langsing terhadap loyalitas pelanggan melalui kepuasan pelanggan. Hal ini menunjukan keberadaan tempat wisata sangatlah diperlukan adanya inovasi dan deferensiasi produk serta menginformasikannya kepada pelanggan dengan sistem informasi pemasaran yang update serta tetap terus mempertahankan palayanan jiga pengunjung telah berada di tempat wisata. 


\section{Pendahuluan}

Setiap tempat wisata memiliki model dan ciri sendiri, demikian halnya dengan generasi yang ada juga memiliki model gaya hidup sendiri pula, ini sudah merupakan ciri khas alamiah. Jatim park sebagai penyedia tempat wisata berdiri sejak tahun 2001an selain berbeda dengan tempat wisata lain juga memiliki perbedaan dengan tempat wisata yang menjadi satu payung Jatim Park seperti museum satwa, dino, eco green park atau mousium angkut hal inilah yang menarik untuk diteliti selain dihubungkan dengan generasi yang ada saat ini yaitu generasi Millenial.

Keanekaragaman tempat wisata yang ada di Jatim Park Group tidak terlepas dari entrepreneur Marketing yang diterapkan oleh perusahaan dengan penggunaan riset pasar yang matang serta dalam rangka mendukung Kota Batu menjadi Kota Destinasi Internasional. Hal lain yang diterapkan adalah diberlakukannya pelayanan kepada pelanggan yang prima serta sistem informasi pemasaran yang update, dan berkualitas. kualitas informasi ini harus benar-benar update dan menarik sehingga dapat memancing minat pengunjung khususnya kaum millennial untuk melihatnya dan pada akhirnya berkunjung ke Jatimpark. Hal lain yang diperhatikan setelah wisatawan berkunjung adalah menjaga kualitas agar wisatanwan yang berkunjung benar- benar merasa puas yang pada akhirnya mau dan merekomendasikan ke orang lain tentang informasi yang baik dan menarik dari keberadaan Jatim park.

Fenomena yang cukup menarik untuk wisatawan millennial saat ini, terbentuknya budaya global dan gaya hidup pop culture (Wahana, 2015). Dimana budaya yang ada saat ini lebih banyak dipengaruhi dengan media yang dengan mudahnya didapat (instant) oleh generasi millenial. Dari gaya hidup yang ada saat ini serta didukung oleh era teknologi tentunya social media akan mempengaruhi suatu generasi untuk menentukan pilihannya dalam berwisata.

Di Amerika Serikat sekitar tahun 1993, awal mula dipakainya sebutan generasi Y atau yang biasa dikenal sebagi generasi millenial. Generasi ini sebenarnya ada tahun 1980, dan sekarang di tahun 2000 an kembali pupoler. Adanya sebutan Generasi millennial karena generasi ini peka terhadap teknologi, tak terkecuali penggunaan internet dan media social yang begitu pesat (Hidayatullah, Waris, \& Devianti, 2018).

Sistem informasi pemasaran merupakan serangkaian proses yang digunakan sebagai bahan pertimbangan dalam pengambilan keputusan (Philip Kotler, 2012). Ada pula yang berpendapat bahwa sistim informasi pemasaran merupakan seraingkaian proses pngumpulan informasi yang dianalisis dan kemudian digunakan untuk menentukan strategi pemasaran suatu perusahaan ("Tourism marketing information and destination image management," 2010).

Service yang diberikan memberikan dampak yang sangat positif bagi konsumen, dan merupakan suatu keunggulan yang dimiliki oleh perorangan ataupun usaha dibidang jasa dan dagang (Tjiptono \& Chandra, 2005). Penilaian negative dan positif dari konsumen yang diberikan oleh suatu instansi atau organisasi dan berdampak pada suatu kepuasan ((Asubonteng, Mccleary, \& Swan, 1996).

Entrepreneurial marketing sebagai serangkaian proses menciptakan, berkomunikasi dan memberikan nilai, dipandu dengan logika mujarab dan digunakan dalam lingkungan bisnis yang sangat tidak pasti (Ioniţă, Dumitru, Constantinescu, \& Căescu, 2015) (Hidayatullah, Firdiansjah, Patalo, \& Waris, 2019).

Menurut (Howat, Murray, \& Crilley, 1999) (Panjaitan \& Yuliati, 2016) ungkapan perasaan yang didapat atau dirasa ketika melakukan suatu atau mengunjungi suatu tempat. Indikator untuk mengukur kepuasan pelanggan adalah: 1. Perbandingan antara kualitas yang diberikan dan harapan yang didapat 2 . Penilaian terdahap tingkat kepuasan dari pribadi seseorang 3. Ada atau tidaknya respon negative atau positif (Shodiq, Hidayatullah, \& Ardianto, 2018) (Amalia \& Murwatingsih, 2016).

Efek yang diberikan oleh setiap konsumen yang mendapatkan nilai positif dari apa yang didapat. Biasanya konsumen tersebut akan dating kembali apabila mengunjungi suatu tempat, membeli kembali suatu produk. Situasi ini biasa dikenal dengan perubahan perilaku seseorang terhadap suatu objek yang dibeli atau dicari (P. Kotler \& Keller, 2009). 


\section{Metode Penelitian}

Penelitian ini merupakan penelitian deskriptif kuantitatif dengan melihat gambaran mengenai situasi atau kejadian. Variabel yang digunakan dalam penelitian ini terdiri atas variabel bebas (Sistem Informasi Pemasaran, Kualitas pelayanan dan Entrepreneur Marketing), Variabel terikat (Loyalitas pengunjung) serta variabel intervening (kepuasan pengunjung). Data dikumpulkan dengan cara survey, penyebaran kuesioner serta telaah pustaka. Lokasi penelitian ada di 6 (enam) lokasi milik Jatim Park Group, populasi penelitian iniadalah semua pengunjung usia milenial yang pernah berkunjung ke Jatim Park Group dengan jumlah sampel sebesar 120 responden dengan karakteristik sampel usia milenial (usia antara 15-34 tahun). Analisa yang digunakan adalah uji f, uji t, dan uji regresi dengan 2 model. Dan dapat dilihat pada konsep di gambar 1 :

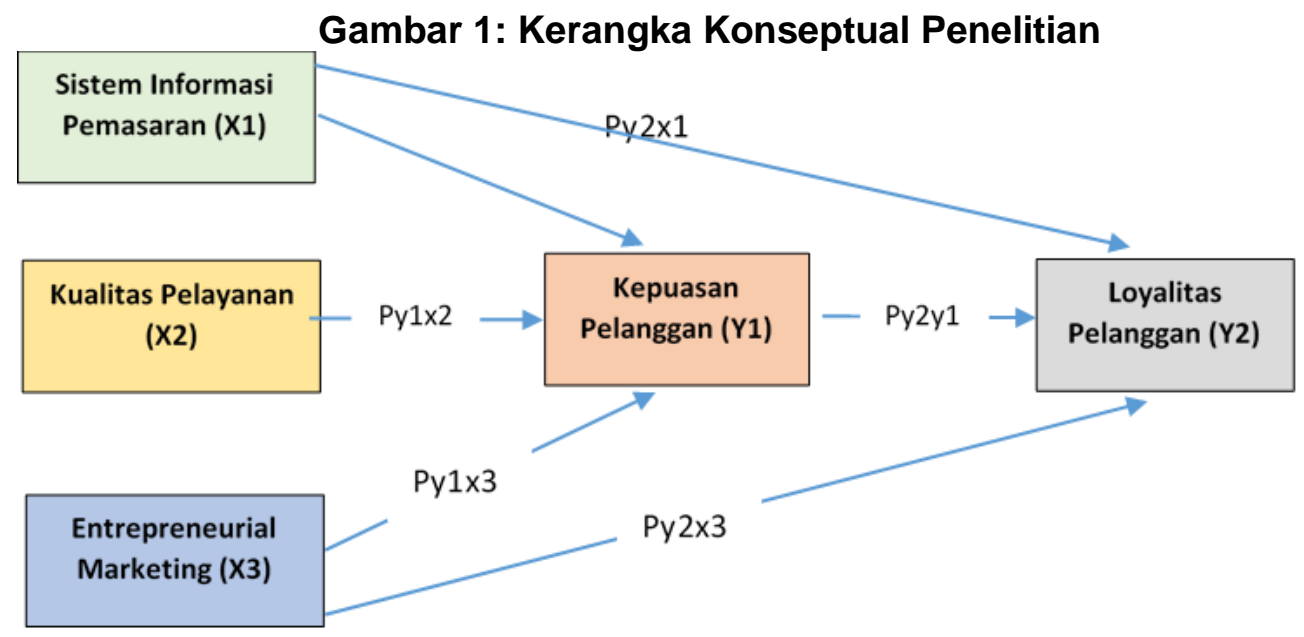

\section{Hasil Penelitian dan Pembahasan}

Hasil Analisis Regresi Model 1

$$
Y_{1}=p y_{1} x_{1}+p y_{1} x_{2}+p y_{1} X_{3}+\varepsilon_{1}
$$

Tabel 1: Output Hasil Regresi Model 1

\begin{tabular}{|c|c|c|c|c|c|}
\hline \multirow[t]{2}{*}{ Model } & \multicolumn{2}{|c|}{$\begin{array}{l}\text { Unstandardized } \\
\text { Coefficients }\end{array}$} & \multirow{2}{*}{$\begin{array}{c}\text { Standardized } \\
\text { Coefficients } \\
\text { Beta }\end{array}$} & \multirow[t]{2}{*}{$\mathbf{T}$} & \multirow[t]{2}{*}{ Sig. } \\
\hline & B & Std.Error & & & \\
\hline (Constant) & 0,949 & 0,481 & & 1,975 & 0,051 \\
\hline $\begin{array}{l}\text { Sistem Informasi } \\
\text { Pemasaran }\end{array}$ & 0,331 & 0,093 & 0,298 & 3,546 & 0,001 \\
\hline Kualitas Pelayanan & 0,043 & 0,110 & 0,033 & 0,394 & 0,694 \\
\hline Entreprenurial Marketing & 0,421 & 0,079 & 0,419 & 5,322 & 0,000 \\
\hline Dependent Variabel & \multicolumn{5}{|c|}{ Kepuasan pengunjung } \\
\hline $\mathrm{R}$ & \multicolumn{5}{|c|}{0,591} \\
\hline $\mathrm{R}_{2}$ & \multicolumn{5}{|c|}{0,349} \\
\hline $\mathrm{R}_{2}$ Adjusted & \multicolumn{5}{|c|}{0,332} \\
\hline $\mathrm{F}$ hitung & \multicolumn{5}{|c|}{20,751} \\
\hline Probability & \multicolumn{5}{|c|}{0,000} \\
\hline Line Equation & \multicolumn{5}{|c|}{$Y_{1}=p y_{2} X_{1}+p y_{2} y_{1}+p y_{2} X_{3}+\varepsilon_{1}$} \\
\hline Result & \multicolumn{5}{|c|}{$Y 1=0,298 x_{1}+0,033 X_{2}+0,419 X_{3}+\varepsilon_{2}$} \\
\hline
\end{tabular}


Hasil regresi pada model 1 memperoleh nilai signifikan $X_{1}=0,000$ dan $X_{3}=0,001$ lebih keci dari 0,05 . Dapat disimpulkan jikayang berpengaruh terhadap $Y$ hanya dua variable yaitu X1 dn X3 yang signifikan dari ketiga variable yang dianalisis. Nilai X2 tidak signifikan karena melebihi nilai atau tingkat alfa yaitu sebesar 0.05 atau $5 \%$. Besarnya nilai $R_{2}$ atau $R_{\text {square }} 0,349$, yang berarti kontribusi yang diberikan dari tiap - tiap variable yang dianalisis terhadap variable $Y$ sebesar $34,9 \%$, dan sisanya $65,1 \%$ merupakan kontribusai dari variable lain yang tidak dianalisis dalam penelitian ini. Dan nilai e1 $=\sqrt{ }(1-$ $0,349)=\sqrt{ }(0,651)=0,807$

Uji hipotesis menggunakan uji $f$ digunakan untuk mengtahui kebenaran atau kesalahan dari model regresi. Dan hasil output hasil regresi model I diperoleh hasil $F$ hitung 20,751 dan nilai signifikan 0,000, mempunyai arti $0,000<0,05$ maka $\mathrm{HO}$ di tolak dan $\mathrm{H} 1$ di terima artinya ada hubungan antara sistem informasi pemasaran, kualitas pelayanan dan Entrepreneurial marketing terhadap kepuasan pelanggan.

Hasil Analisis Regresi Model 2

$$
Y_{2}=p y_{2} X_{1}+p y_{2} y_{1}+p y_{2} X_{3}+\varepsilon_{2}
$$

Tabel 2 : Output Hasil Regresi Model 2

\begin{tabular}{|c|c|c|c|c|c|}
\hline \multirow[t]{2}{*}{ Model } & \multicolumn{2}{|c|}{$\begin{array}{l}\text { Unstandardized } \\
\text { Coefficients }\end{array}$} & $\begin{array}{l}\text { Standardized } \\
\text { Coefficients }\end{array}$ & \multirow[t]{2}{*}{$\mathbf{T}$} & \multirow[t]{2}{*}{ Sig. } \\
\hline & B & Std.Error & Beta & & \\
\hline (Constant) & 0,135 & 0,323 & & 0,417 & 0,677 \\
\hline $\begin{array}{l}\text { Sistem Informasi } \\
\text { Pemasaran }\end{array}$ & 0,103 & 0,073 & 0,091 & 1,418 & 0,159 \\
\hline $\begin{array}{l}\text { Entrepreneurial } \\
\text { marketing }\end{array}$ & 0,354 & 0,069 & 0,346 & 5,114 & 0,000 \\
\hline Kepuasan Pelanggan & 0,508 & 0,073 & 0,499 & 6,940 & 0,000 \\
\hline Dependent Variabel & \multicolumn{5}{|c|}{ Loyalitas pelanggan } \\
\hline $\mathrm{R}$ & \multicolumn{5}{|c|}{0,781} \\
\hline $\mathrm{R}^{2}$ & \multicolumn{5}{|l|}{0,609} \\
\hline $\mathrm{R}^{2}$ Adjusted & \multicolumn{5}{|l|}{0,599} \\
\hline F hitung & \multicolumn{5}{|l|}{60,306} \\
\hline Probability & \multicolumn{5}{|l|}{0,000} \\
\hline Line Equation & \multicolumn{5}{|c|}{$Y_{2}=p y_{2} X_{1}+p y_{2} y_{1}+p y_{2} X_{3}+\varepsilon_{2}$} \\
\hline Result & \multicolumn{5}{|c|}{$Y_{2}=0,091 x_{1}+0,499 y_{1}+0,346 X_{3}+\varepsilon_{2}$} \\
\hline
\end{tabular}

Selanjutnya hasil output regresi Model II diketahui signifikan nilai dari ketiga variabel. Dengan membandingkan alfa $5 \%$ diperoleh hasil $X_{1}=0,159$ tidak berpengaruh signifikan terhadap $Y_{2}$ dan $X_{2}=0,000, X_{3}=0,000$, lebih keci dari 0,05 . artinya hanya dua variable yang signifikan yaitu $X 2$ dan $X 3$ terhadap $Y_{2}$. Niali $R^{2}$ atau $R S q u a r e$ yang di dapat sebesar 0,609 , menunjukan besarnya nilai kontribusi disetiap varialbel yang dianalisis terhadap $Y$ adalah sebesar $60,9 \%$, sementara $39,1 \%$ tesebar pada variable lain yang tidak dianalisis dalam penelitian ini. Dengan e1 $=\sqrt{ }(1-0,609)=\sqrt{ }(0,391)=0,625$. Uji F penelitian model II diperoleh hasil $F$ hitung 60,309 dengan nilai signifikan 0,000 , menunjukkan $0,000<0,05$ maka $\mathrm{H} 0$ ditolak dan $\mathrm{H} 1$ di terima artinya sistem informasi pemasaran, Entrepreneurial marketing dan kepuasan pelanggan dengan Bersama-sama memiliki hubungan dengan loyalitas pelanggaan. 
Tabel 3 : Hipotesis, pengaruh langsung, tidak lagsung dan total antar variabel

\begin{tabular}{|c|c|c|c|c|c|}
\hline & Hipotesis & $\begin{array}{l}\text { Pengaruh } \\
\text { Langsung }\end{array}$ & $\begin{array}{l}\text { Pengaruh Tidak } \\
\text { Langsung }\end{array}$ & $\begin{array}{l}\text { Pengaruh } \\
\text { Total }\end{array}$ & Keterangan \\
\hline 1 & $\mathrm{X} 1 \rightarrow \mathrm{Y} 1$ & 0,298 & & & signifikan \\
\hline 2 & $\mathrm{X} 2 \rightarrow \mathrm{Y} 1$ & 0,033 & & & Tidak signifikan \\
\hline 3 & $\mathrm{X} 3 \rightarrow \mathrm{Y} 1$ & 0,419 & & & Signifikan \\
\hline 4 & $\mathrm{X} 1 \rightarrow \mathrm{Y} 2$ & 0,091 & & & Tidak Signifikan \\
\hline 5 & $X 3 \rightarrow Y 2$ & 0,346 & & & Signifikan \\
\hline 6 & $\mathrm{Y} 1 \rightarrow \mathrm{Y} 2$ & 0,499 & & & Signifikan \\
\hline 7 & $\mathrm{X} 1 \rightarrow \mathrm{Y} 1 \rightarrow \mathrm{Y} 2$ & & $\begin{array}{l}(X 1 \rightarrow Y 1) \times(Y 1 \rightarrow Y 2) \\
0,298 \times 0,499= \\
0,149\end{array}$ & 0,240 & $\begin{array}{l}\mathrm{X} 1 \quad \text { melalui } \mathrm{Y} 1 \\
\text { mempunyai } \\
\text { pengaruh } \\
\text { signifikan } \\
\text { terhadap } \mathrm{Y} 2\end{array}$ \\
\hline 8 & $\mathrm{X} 3 \rightarrow \mathrm{Y} 1 \rightarrow \mathrm{Y} 2$ & & $\begin{array}{l}(X 3 \rightarrow Y 1) \times(Y 1 \rightarrow Y 2) \\
0,419 \times 0,499= \\
0,209\end{array}$ & 0,555 & $\begin{array}{l}\text { X3 melalui } \mathrm{Y} 1 \\
\text { mempunyai } \\
\text { pengaruh tidak } \\
\text { signifikan } \\
\text { terhadap Y2 }\end{array}$ \\
\hline
\end{tabular}

Uji t yang digunakan pada hipotesis adalah untuk memperoleh hasil pengaruh variabel yang signifikan daei variable bebas terhadap variable terikat serta variable moderating dengan melihat nilai probabillitas $(<0,05)$.

\section{Uji Hipotesis ke 1}

Hasil uji t tabel 1 di ketahui Sistem informasi pemasaran ternyata berpengaruh positife dan signifikan pada kepuasan pelanggan yang berkunjung di Jatim Park group. Dan bias di lihat karena probabillitasnya kurang dari $(>0,05)$ yaitu 0,001 . Kesimpulan : untuk hipotesis kesatu dapat di terima atau teruji secara statistik. Berpengaruh signifikannya peran sistem informasi pemasaran terhadap kepuasan pelanggan sangat wajar, karena sistem usaha modern saat ini sudah mengedepankan sistem informasi yang online dan sistem informasi yang berkualitas yang disajikan dalam bentuk website (Stephanie, Hidayatullah, \& Ardianto, 2019) (Rakhmadian, Hidayatullah, Respati, \& Malang, 2017) (Shodiq et al., 2018) sehingga usia milenial yang menjadi sampel penelitian lebih memilih tempat berwisata dari informasi yang didapat secara mudah dan online. Informasi yang didapat kaum milenial melalui online sangat dapat mempercepat penyebarannya dan sugesti akan kondisi dan kberadaan tempat wisata tersebut itu juga akan dapat mempengaruhi kepuasan pengunjung sehingga sistem informasi tersebut dapat membantu menciptakan kepuasan.

\section{Uji Hipotesis ke 2}

Hasil uji t pada tabel 1 diketahui kualitas pelayanan ternyata berpengaruh positife tapi tidak signifikan pada kepuasan pelanggan yang datang berkunjung ke tempat jatim park , ditemukan probabillitasnya lebih besar dari <0,05 yaitu 0,694. Kesimpulan, hipotesis kedua berbunyi terdpat pengaruh signifikan anatara kwalitas pelayanan dana kepuasan pelanggan lewat statistik tidak teruji. Hal ini disebabkan karena responnden millennial yang menjadi sampel penelitian memiliki karakteristik yang unik dalam mewujudkan keinginannya, dan menjadikan pelayanan yang berkualitas bukan tujuan utama responden namun keberagaman tempat wisata yang menarik serta uniklah yang menjadikan kepuasan, hal ini bisa terjadi karena mereka sadar tempat wisata manapun pasti akan dan sudah menstandarkan kualitas pelayanan bagi semua pelanggannya, namun dari sudut mana kita akan menilainya.

\section{Uji Hipotesis ke 4}


Tabel 2 diketahui sistem informasi pemasaran tidak ada pengaruh signifikan terhadap loyalitas pelanggan dalam berkunjung ke jatim park, ditemukan probabilitasnya lebih besar $(<0,05)$ yaitu sebesar 0,159 . Kesimpulan hipotesis keempat secara statistik tidak teruji. Penelitian ini menggambarkan bahwa informasi yang diberikan perusahaan tidak sematamata langsung dapat meningkatkan pelanggan tersebut loyal, namun sistem informasi yang ada bertujuan untuk memberikan gambaran tentang kondisi perusahaan dalam hal ini jatim park tentang wahana dan apa saja yang ada didalammnya yang pada akhirnya pelanggan akan membandingkan apa yang disampaikan dengan kenyataan, hal inilah yang dapat menimbuklan kepuasan dari pelanngan yang pada akhirnya dapat membuat pelanggan loyal, bukan informasi yang ada membuat pelanggan menjadi loyal.

\section{Uji Hipotesis ke 5}

Hasil uji t pada tabel 2 diketahui Entrepreneurial marketing berpengaruh yang positife dan signifikan pada loyalitas pelanggan yang berkunjung di destinasi jatim park Kota Batu, ditemukan probabilitasnya lebih kecil $(>0,05)$ dengan nilai 0,000 . Kesimpulannya : Bila Entrepreneurial marketing ditingkatkan maka loyalitas pelanggan akan meningkat karena pelanggan usia milleniaal di penelitian ini sangat sensitive terhadap perubahan dan keinginan usia milleniaal yang berkeinginan coba - coba pada hal baru sehingga dibutuhkan inovasi dan kreativitas yang terus dan berkelanjutan (Christian, 2017)(Wahono \& Effrisanti, 2018) dan hal ini sudah dialkukan oleh jatim park dengan terus berimprovisasi dengan terus membuka tempat wisata baru yang up to date dan kekinian.

\section{Uji Hipotesis ke 6}

Tabel 2 diketahui kepuasan pelanggan memiliki berpengaruh positif dan signifikan pada loyalitas pelanggan yang berkunjung di destinasi Jatim Park Kota Batu. Hal ini dilihat dari besarnya nilai probabilitasnya yang berada dibawah $(>0,05)$ yaitu 0,000 . Kesimpulan bahwa jika pelanggan puas akan membentuk embrio loyaliyas pelanggan karena keinginan untuk berkunjung kembali semakin besar (Atmaja, 2018) untuk berkunjung kembali ke Jatim park karena kunjungan sebelumnya pelanggan sudah mendapatkan sesuatu yang mengesankan.

\section{Uji Hipotesis ke 7}

Pada Tabel 3 menunjukkan bahwa kepuasan pelanggan sebagai variabel moderating antara sistem informasi pemasaran terhadap loyalitas pelanggan bisa di lihat oleh besarnya indirect effect $(0,149)$ di bandingkan direct effect $(0,091)$ yang muncul dari sistem informasi pemasaran dapa kepuasan pelanggan. Kesimpulan dengan meningkatkan sistem informasi pemasaran maka kepuasan pelanggan jatim Park juga akan meningkat dan selanjutnya peningkatan ini juga akan diikuti dengan peningkatan loyalitas dari pelanggan. Konsep sistem informasi pemasaran merupakan suatu faktor yang terdepan dalam hal menginformasikan kondisi yang ada di perusahaan sehingga keberhasilan suatu perusahaan dalam memasarkan suatu produk tergantung sistem informasi pemasaran yang digunakan (Handita, Umar, \& Fadillah, 2012)(Wibowo, 2017). Demikian halnya dengan usia milleniaal yang menjadi sampel dalam penelitian ini yang kesehariannya sudah menggunakan teknologi informasi dalam mendapatkan suatu informasi sehingga sistem informasi yang berkualias dan menarik merupakan salah satu magnet untuk membuat kaum milenial berkunjung ke jatim park Kota Batu.

\section{Uji Hipotesis ke 8}

Tabel 3 menunjukkan bahwa Kepuasan pelanggan menjadi variabel moderating antara Entrepreneurial marketing terhadap loyalitas pelanggan bias di lihat dari besar indirect effect $(0,209)$ di bandingkan direct effect $(0.346)$ yang muncul darii Entrepreneurial marketing pada kesetiaan pelanggan. Artinya dengan menerapkan Entrepreneurial marketing akan berdampak secara langsung dan lebih efektif pada peningkatan loyalitas atau kesetiaan pengunjung Jatim Park yang nantinya Customer itu sendiri yang akan 
menentukan tingkat kepuasan yang didapat. (Sulistiyana, 2015)(Susilo, Heri; Haryono, Andi Tri; W, 2018)(Khouroh, Sudiro, Rahayu, \& Indrawati, 2020).

Membantuk kepuasan pelanggan khususnya kepuasan kelompok millenial sangat berpengaruh dengan sistem informasi pemasaran yang digunakan terutama informasi berupa media online, hal ini disebabkan usia mineliall merupakan kelompok yang sudah terbiasa sejak lahir menggunakan internet sehingga segala sesuatu senantiasa menggunakan internet (Handayani, 2016). Namun informasi yang disampaikan juga informasi yang berkualitas dan benar-benar sesuai dengan keadaan atau kondisi yang ada dilapangan sehingga bisa pelanggan datang akan mendapatkan harapan sesuai dengan kenytaan inilah yang akan dapat membuat kepuasan dan loyalitaa pelanggan (Aryani \& Rosinta, 2010). Selain sistem informasi pemasaran yang handal dan Tampilan yang menarik dari informasi media online factor kualitas pelayanan juga harus dijaga perusahaan karena untuk mencapai kepuasan pelanggan sifatnya multidimensional yang artinya bukan hanya satu variable saja tetapi juga dipengaruhi oleh berbagai aspek. Demikian halnya dengan jatim park group yang memiliki berbagai tempat wahana yang sudah disesuaikan berbagai usia bisa menikmatinya terutama untuk usia milenial. Wahana museum satwa, museum angkut, dino, ecco green park \& ada banyak wahana yang setiap saat terus di up date oleh jatim park group. Hal ini tidak terlepas dari entrepreneur marketing yang menuntuk pengelola senantiasa melihat peluang dan keinginan dari masyarakat tentang kebutuhan wisata yang modern (Morrish, 2011)(RößI, Kraus, \& Fink, 2007), termasuk keinginan dari Jatim Park untuk terus berkarya dan berinvestasi di Kota Batu, hal ini gayung bersambut dengan pemerintah kota batu untuk terus mempermudah investasi di bidang Pariwisata (Windhyastiti, Hidayatullah, \& Khouroh, 2019) untuk mewujudkan Batu Destinasi international.

Hubungannya dengan usia millennial, Jatim Park group sebagai penyedia tempat wisata berusaha untuk meningkatkan fasilitas wisata yang ada selain itu juga berusaha mendekatkan dan memperhatikan kebutuhan usia millenial seperti adanya wahana baru yang update dan menarik serta informasi wahana wisata secara online. Selain itu peningkatan kualitas pelayanan juga selalu di lakukan karena Jatim Park Group sebagai penyedia wahana terbesar wisata di Kota Batu sudah berkomitmen untuk memberikan pelayanan yang terbaik terlebih lagi pada saat hari libur dan hari besar, dimana pengunjung yang ada sangat banyak sehingga perlu adanya pelayanan yang ektra. Dari sisi keberagaman tempat wisata yang berhubungan dengan Entrepreneurial marketing Jatim Park Group juga selalu update dengan keinginan milenial seperti penyediaan tempat wisata kekinian yang dihubungkan dengan edukasi dan pengetahuan sehingga kejenuhan masyarakat akan keberadaan tempat wisata milik kelompok Jatim Park tidak akan terjadi.

\section{IV.Kesimpulan}

Kesimpulan dalam penelitian ini : 1) Sistem informasi pemasaran berpangaruh terhadap kepuasan pengunjung, artinya jika sistim informasi pemasaran ditingkatkan maka kepuasan pengunjung juga meningkat. Sistim informasi yang di maksud di sini adalah sistem informasi yang ter update baik dari sisi konten, berita maupun tampilan sehingga generasi mileniall dapat dengan mudah mengakses berita-berita yang disampaikan di website Jatim Park. 2) kualitas pelayanan tidak berpengaruh kepada kepuasan pengunjung, ini bisa disebabkan pada usia millennial yang lebih memfokuskan pada produk atau wahana wisata yang ada sedangkan setiap wahana di jatim park sudah tersedia personil khusus untuk pelayanan, 3) Entrepreneurial marketing berpengaruh terhadap kepuasan pengunjung, hal ini terjadi disebabkan jatim park senantiasa membuat sesuatu yang baru khususnya tentang destinasi wiasta yang terdapat di Kota Batu sehingga kebutuhan kaum milleniall dapat terpenuhi dengan mengunjungi jatim park., 4) sistem informasi pemasaran tidak berpengaruh langsung pada loyalitas pelanggan wisata jatim park, artinya peningkatan sistem informasipemasaran tidak akan meningkatkan loyalitas pelanggan, 5) Entrepreneurial marketing ber pengaruh langsung pada loyalitas pelanggan Jatim Park, artinya jika wahana 
dalam jatim Park ditingkatkan akan meningkatkan loyalitas pelanggan, 6) Kepuasan pelanggan ber pengaruh langsung pada loyalitas pelanggan, berarti jika kepuasan pelanggan meningkat makana akan meningkatkan loyalitas pelanggan untuk berkunjung kembali ke Jatim Park. 7) Sistem Informasi Pemasaran berpengaruh secara tidak langsung pada loyalitas pelanggan tempat jatim park melalui kepuasan pelanggan, pengertiannya jika dengan meningkatkn sistem informasi pemasaran maka loyalitas pelanggan jadi naik melalui kepuasan pelanggan, 8) Entrepreneurial marketing ber pengaruh secara langsung dan tidak langsung pada loyalitas pelanggan tempat jatim park melalui kepuasan pelanggan, pengertiannya jika dengan menerapkan Entrepreneurial marketing jadi akan lebih efektif agar loyalitas pelanggan semakin meningkat tanpa harus melihat kepuasan pelanggan.

Saran dalam penelitian ini, setiap hari bahkan hari libur dan hari besar pengunjung yang datang Jatim Park Grup sangat banyak bahkan membuat jalan disekitarnya menjadi macet, namun kemacetan yang ada dapat menjadi wahana tersendiri bagi pengunjung karena bisa memankan waktu berjam-jam untuk sampai ke lokasi wisata. Jadi, pemanfaatan dan kerjasama dengan masayarakat sekitar sangat penting atau dengan pemberdayaan masyarakat local seperti kerjasama dengan kelompok sadar wisata atau yang di kenal (pokdarwis) di kota Batu karena di kota Batu sendiri pokdarwis sudah sangat berkembang dengan menjual berbagai macam atraksi wisata alam (Hidayatullah, Malang, et al., 2018). Dan pengembangan kuliner disepanjang jalan menuju jatim park juga harus ditingkatkan juga dapat disulap untuk mengurangi kejenuhan terlebih lagi jika yang berkunjung adalah usia millennial yang dibutuhkan kuliner yang bersifat online (Syarif Hidayatulloh, 2018).selain itu dukungan pemerintah Kota Batu juga sangat berpengaruh terhadap pekembangan serta maju tidaknya pariwisata yang ada .(Windhyastiti \& Widiawati, 2016).

Masih banyak Faktor yang mempengaruhi generasi millennial dalam menenutukan tempat wisata selain yang penulis teliti, selain itu hasil yang diperoleh peneliti dengan variabel yang sama juga bisa berbeda hasilnya bila diterapkan ditempat lain, hal ini tergantung pada lokasi, waktu serta karakteristik tempat wisata sehingga disarankan peneliti lain dapat mengembangkan variabel dan penentuan lokasi yang berbeda.

\section{Daftar Pustaka}

Amalia, I., \& Murwatingsih. (2016). Pengaruh citra destinasi dan nilai pelanggan terhadap loyalitas pengunjung melalui kepuasan pengunjung. Management Analysis Journal.

Aryani, D., \& Rosinta, F. (2010). Pengaruh Kualitas Layanan terhadap Kepuasan Pelanggan dalam Membentuk Loyalitas Pelanggan. Jurnal Ilmu Administrasi Dan Organisasi.

Asubonteng, P., Mccleary, K. J., \& Swan, J. E. (1996). SERVQUAL revisited: A critical review of service quality. Journal of Services Marketing. https://doi.org/10.1108/08876049610148602

Atmaja, J. (2018). Kualitas Pelayanan dan Kepuasan Nasabah Terhadap Loyalitas Pada Bank BJB. Jurnal Ecodemica.

Christian, M. (2017). PENGARUH FAKTOR PERILAKU PADA KELOMPOK MILLINEAL TERHADAP KEINGINAN UNTUK BERWIRAUSAHA. Journal of Business \& Applied Management. https://doi.org/10.30813/jbam.v10i02.930

Handayani, S. N. (2016). Strategi Kemenpar Gaet Milenial Majukan Pariwisata.

Handita, D. B., Umar, \& Fadillah, U. (2012). Sistem Informasi Penjualan Berbasis Web. Jakarta. https://doi.org/10.1111/evo.12175

Hidayatullah, S., Firdiansjah, A., Patalo, R. G., \& Waris, A. (2019). The effect of entrepreneurial marketing and competitive advantage on marketing performance. International Journal of Scientific and Technology Research.

Hidayatullah, S., Malang, U. M., Khouroh, U., Malang, U. M., Windhyastiti, I., \& Malang, U. M. (2018). Development of Tourist Village Model Through "Pokdarwis" Empowerment and Information Technology Utilization. European Journal of Business and Management, (January). https://doi.org/10.7176/ejbm-10-23-12 
Hidayatullah, S., Waris, A., \& Devianti, R. C. (2018). Perilaku Generasi Milenial dalam Menggunakan Aplikasi Go-Food. JURNAL MANAJEMEN DAN KEWIRAUSAHAAN. https://doi.org/10.26905/jmdk.v6i2.2560

Howat, G., Murray, D., \& Crilley, G. (1999). The relationships between service problems and perceptions of service quality, satisfaction, and behavioral intentions of Australian public sports and leisure center customers. Journal of Park \& Recreation Administration.

Ioniţă, D., Dumitru, I., Constantinescu, M., \& Căescu, Ş. (2015). Entrepreneurial clusters in European Union. A macroeconomic comparative analysis. Amfiteatru Economic.

Khouroh, U., Sudiro, A., Rahayu, M., \& Indrawati, N. K. (2020). The mediating effect of entrepreneurial marketing in the relationship between environmental turbulence and dynamic capability with sustainable competitive advantage: An empirical study in Indonesian MSMEs. Management Science Letters. https://doi.org/10.5267/j.msl.2019.9.007

Kotler, P., \& Keller, K. L. (2009). Marketing management (13th ed.). In Prentice Hall.

Kotler, Philip. (2012). Marketing management/Philip Kotler, Kevin Lane Keller. In Marketing management.

Morrish, S. C. (2011). Entrepreneurial marketing: A strategy for the twenty-first century? Journal of Research in Marketing and Entrepreneurship. https://doi.org/10.1108/14715201111176390

Panjaitan, J. E., \& Yuliati, A. L. (2016). Pengaruh Kualitas Pelayanan Terhadap Kepuasan Pelanggan Pada JNE Cabang Bandung. DeReMa (Development Research of Management): Jurnal Manajemen.

Rakhmadian, M., Hidayatullah, S., Respati, H., \& Malang, U. M. (2017). Analisis Kualitas Sistem Dan Kualitas Informasi Terhadap Kepuasan Pemakai Sistem Informasi Akademik Dosen. Seminar Nasional Sistem Informasi, (September), 665-675.

Rößl, D., Kraus, S., \& Fink, M. (2007). Entrepreneurial Marketing. WiSt Wirtschaftswissenschaftliches Studium. https://doi.org/10.15358/0340-1650-2007-12590

Shodiq, A. F., Hidayatullah, S., \& Ardianto, Y. T. (2018). INFLUENCE OF DESIGN, INFORMATION QUALITY AND CUSTOMER SERVICES WEBSITE ON CUSTOMER SATISFACTION. 9(12), 746-750.

Stephanie, A., Hidayatullah, S., \& Ardianto, Y. T. (2019). An Emperical Study of Website Quality on Hotel Booking Online. 4(2), 10-14.

Sulistiyana, R. (2015). PENGARUH FASILITAS WISATA DAN HARGA TERHADAP KEPUASAN KONSUMEN (STUDI PADA MUSEUM SATWA). Jurnal Administrasi Bisnis $S 1$ Universitas Brawijaya.

Susilo, Heri; Haryono, Andi Tri; W, M. M. (2018). Analisis Pengaruh Harga, Kualitas Pelayanan, Promosi, Dan Kepercayaan Terhadap Kepuasan Konsumen Dengan Keputusan Berkunjung Sebagai Variabel Intervening Di Hotel Amanda Hills Bandungan. Maharaja Agrasen Institute of Management and Technology Journal of IT \& Management.

Syarif Hidayatulloh, D. (2018). Eksistensi Transportasi Online ( Go Food ) Terhadap Omzet Bisnis. Seminar Nasional Sistem Informasi , Fakultas Teknologi IInformasl, 1423-1429.

Tjiptono, F., \& Chandra, G. (2005). Manajemen Kualitas Jasa. Yogyakarta. ANDI. https://doi.org/10.12691/jbms-4-4-1

Tourism marketing information and destination image management. (2010). African Journal of Business Management.

Wahono, H. T. T., \& Effrisanti, Y. (2018). Literasi Digital di Era Millenial. Prosiding Seminar Nasional Hasil Penelitian Pendidikan Dan Pembelajaran STKIP PGRI Jombang.

Wibowo, A. (2017). Kajian Tentang Perilaku Pengguna Sistem Informasi Dengan Pendekatan Technology Acceptance Model ( TAM ). Konferensi Nasional Sistem Informasi.

Windhyastiti, I., Hidayatullah, S., \& Khouroh, U. (2019). How to increase city investment attraction. International Journal of Scientific and Technology Research. 
Windhyastiti, I., \& Widiawati, D. (2016). PENTINGNYA ASPEK GOVERMENT POWER DALAM PENGEMBANGAN INDUSTRI PARIWISATA DAERAH. JURNAL MANAJEMEN DAN KEWIRAUSAHAAN. https://doi.org/10.26905/jmdk.v4i1.405 